\title{
SOME ASPECTS OF THE CULTURE OF EUCHEUMA
}

\author{
by
}

\author{
U. Horstman ${ }^{1)}$, A. Colina ${ }^{1)}$ and W. Schramm ${ }^{1)}$
}

\begin{abstract}
Eucheuma striatum and Eucheuma spinosum, are red algae of commercial value because of their carrageenin content, to an increasing extent are cultivated in the Philippines. The influence of environmental factors on growth rate and photosynthesis of these seaweeds were studied through observations in their natural biotope in seaweed farms, from in-situ experiments, and photosynthesis experiments in an incubator.

While difference in light intensity and temperature play only a minor role, the algae were found out to be sensitive to low salinity and to the amount of dissolved gases and nutrients in the surrounding seawater.

The algae can only be cultured in areas where there is sufficient current but to a certain extent lack of current can be compensated by exposing the plants to wave action. This leads to certain conclusions regarding the most suitable method of commercial Eucheuma culture. Eucheuma can be successfully cultured in small rafts or in floating baskets in areas where there is insufficient current for the use of fixed nets or strings.

There is evidence that the $\mathrm{CO}_{2}-\mathrm{O}_{2}$ metabolism in the surrounding water plays an important role in Eucheuma growth.

Eucheuma harvest can be further increased by introducing more nutrients. Fertilizing with phosphate caused a bigger increase in growth rate than with nitrogen. The method of spraying plants after temporarily removing them from the water, found to be more effective than fertilizing solutions by the use of clay pots.

The presence of a bacterial disease, locally referred to as "ice-ice", was recognized as a clear indication that certain environment conditions were unfavourable for Eucheuma culture. Low salinity, in the first place, but also lack of current favors the attack of "ice-ice".

Finally, it was found that Eucheuma adapts itself to its culture site in such a way that after maintaining seedlings in an area for a sufficient length of time, the cultured plants showed better growth rates and were resistent to unfavorable conditions than plants recently transferred to the area.
\end{abstract}

1). Marine Research Office, University of San Carlos, Cebu City, 6401, Philippines. 